\title{
HARD LAW, SOFT LAW AND DIPLOMACY: THE EMERGING PARADIGM FOR INTERGOVERNMENTAL COOPERATION IN ENVIRONMENTAL ASSESSMENT
}

\author{
STEVEN A. KENNETT*
}

The author uses a paradigm derived from international law to assess the evolution of federalprovincial cooperation in environmental assessment (EA) in Canada. He examines the development of intergovernmental diplomacy and the evolution from soft to harder law through such measures as intergovernmental agreements on EA and legislation. Intergovermmental cooperation in EA is described in its constitutional context and its development is analyzed from a legal perspective. An examination of recent judicial decisions concerning major interiurisdictional projects underlines the need for cooperative EA arrangements. Four stages of the hardening of soft law are identified to illustrate how the legal framework for intergovernmental cooperation in EA may progress from general principles to formal intergovernmental arrangements and legally binding rules.
L'auteur utilise un paradigme découlant du droit international pour examiner l'évolution de la coopération fédérale-provinciale en matière d'évaluation des incidences environnementales (EIE) au Canada. L'auteur suit l'évolution de la diplomatie intergouvernementale et le durcissement des lois en étudiant les ententes intergouvernementales et la législation relatives à l'EIE. La coopération entre les gouvernements est décrite dans son contexte constitutionnel, et son évolution est analysée du point de vue juridique. Un examen des décisions juridiques récentes portant sur des projets relevant de plus d'une juridiction mes en évidence la nécessité de parvenir à des arrangements coopératifs. Quatre étapes de durcissement des lois sont proposées pour illustrer la façon dont le cadre légal régissant la coopération intergouvernemental en EIA peut évoluer pour passer de principes généraux à des conventions et à des règles intergouvernementales officielles ayant force d'obligation.

\section{TABLE OF CONTENTS}

I. INTRODUCTION ..................... 644

II. THE INTERNATIONAL PARADIGM $\ldots \ldots \ldots \ldots \ldots \ldots \ldots 645$

III. THE CONSTITUTIONAL CONTEXT $\ldots \ldots \ldots \ldots \ldots \ldots \ldots 647$

IV. LIMITATIONS OF THE CONSTITUTIONAL POSITION ........................650

V. THE DEVELOPMENT OF INTERGOVERNMENTAL

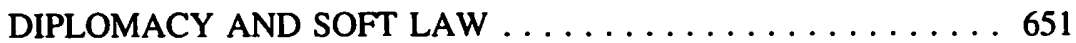

VI. INTERGOVERNMENTAL AGREEMENTS ON EA AND THE EVOLUTION FROM SOFT TO HARD(ER) LAW

VII. PROSPECTS FOR THE HARDENING OF THE LAW GOVERNING INTERGOVERNMENTAL

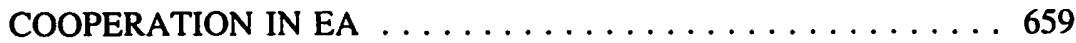

VIII. CONCLUSION $\ldots \ldots \ldots \ldots \ldots \ldots \ldots \ldots \ldots \ldots \ldots \ldots 61$

\section{INTRODUCTION}

The increasing complexity and cost of environmental assessment (EA) in Canada have made minimizing duplication and procedural uncertainty a principal concern of project 
proponents, intervenors and governments. With the recognition of EA as a central component of government decision-making throughout Canada, this concern has an important federal dimension. Establishing efficient, comprehensive and legitimate EA regimes is especially difficult when projects are subject to jurisdictional overlap or when they produce transboundary effects. Interjurisdictional issues in EA, raised in both judicial and administrative forums in Canada, are a major challenge confronting Canadian federalism in the area of environmental law and policy.

This article applies a paradigm, derived from international law, to the development of intergovernmental cooperation in environmental assessment. The international paradigm highlights the relationship between intergovernmental diplomacy and law. The article begins by outlining the international paradigm. The constitutional context of intergovernmental cooperation in EA is then described and its limitations noted. In the following sections, the development of intergovernmental cooperation in EA is reviewed and then analyzed from a legal perspective. Finally, the prospects for the development of a legal framework for EA coordination are briefly discussed.

\section{THE INTERNATIONAL PARADIGM}

The analogy between intergovernmental relations within federalism and the international system can be considered from political science and legal viewpoints. It is suggested in the title of Richard Simeon's book Federal-Provincial Diplomacy, ${ }^{1}$ a seminal discussion of the politics of negotiations between the federal government and the provinces. ${ }^{2 .}$ The legal analogy has been drawn by J. Owen Saunders, ${ }^{3}$ taking as a starting point the concept of sovereignty, the defining legal characteristic of the international system. Problems raised by sovereignty may be replicated within federal systems ${ }^{5}$ since national and sub-national governments exercise powers, defined by the Constitution, within territorial limits. ${ }^{6}$ Sovereignty, in both federal and international systems, causes particular difficulties when issues are the subject of shared responsibility between governments or when they fail to respect political boundaries. Environmental management provides

R.E.B. Simeon, Federal-Provincial Diplomacy (Toronto: University of Toronto Press, 1972).

For Simeon's discussion of the analogy between federal-provincial negotiations and the international system, see ibid. at 11, 299-300, 309-310.

3 J.O. Saunders, "Sharing Environmental Management: A Legal Perspective" (Paper presented at the International Conference on Environmental Management: The Sharing of Responsibilities Between Levels of Government, Lac Beauport, Quebec, 4.6 December 1992) [unpublished].

$4 \quad$ lbid. at 2.

$3 \quad$ Ibid. at 11.

6 Sovereignty in the federal context is not, of course, unfettered. The authority of each level of government is constrained by the constitutional division of powers. In addition, one level of government may have a power of jurisdictional override in certain circumstances. For example, the "peace, order and good government" power in the Canadian Constitution allows Parliament to intrude on traditional areas of provincial jurisdictions in the event of a national emergency. Federal declaratory and disallowance powers, both of which appear to be moribund, also allow Parliament to prevail over provincial authority. See P.W. Hogg, Constitutional Law of Canada, 3d ed. (Toronto: Carswell, 1992) at 452-462, 115, 112. 
numerous examples of these types of issues. ${ }^{7}$ In the international sphere, Saunders argues, "soft" law is developed to overcome problems caused by sovereignty. ${ }^{8}$. This article shows that a similar process can occur within Canada's federal system.

The concepts of "hard" and "soft" law are central to the international law paradigm. Hard law consists of legally binding rules or obligations which may be interpreted and enforced by courts or other authoritative tribunals. The precise nature of "soft" law and the extent to which it is "law" at all remain matters of some debate among international lawyers. ${ }^{9 .}$ The content and role of this concept, however, have been explored in considerable detail. ${ }^{10}$. The term "soft law" can be applied to a cluster of related phenomena associated with the formation of international law. The first of these is "prelaw." Emerging norms or principles which may later be adopted, either formally or as a matter of practice, can be characterized as soft law. ". Second, soft law designates rules which may not be binding ${ }^{12 .}$ or fully enforceable, but which nonetheless have a certain legal status or impact on international law. ${ }^{13}$. Finally, soft law refers to a "transitional stage in the development of norms where their content is vague and their scope

For example, Saunders attributes the failure of international legal norms to address the environmental problems of managing the global commons to an insistence on the principle of sovereignty. (Saunders, supra note 3 at 4.) Sovereignty also complicates transboundary resource management and pollution control, both internationally and within federal systems. This problem is illustrated by Canadian water management. The Inquiry on Federal Water Policy concluded that: "The prevailing uncertainty surrounding interjurisdictional waters is the most fundamental deficiency in Canada's water policy." P.H. Pearse, F. Bertrand \& J.W. MacLaren, Currents of Change Inquiry on Federal Water Policy, (Final Report) by P.M. Pearse, F. Bertrand \& J.W. MacLaren (Ottawa: Environment Canada, 1985) at 73. Saunders, supra note 3 at 9.

R. Bernhardt, "Customary International Law" in R. Bernhardt, ed., Encyclopedia of Public International Law, vol. 7 (Amsterdam: Elsevier Science Publishers B.V., 1984) 61 at 62. For useful discussions of practical and theoretical issues related to the concept of soft law, see: M. Bothe, "Legal and Non-Legal Norms - A Meaningful Distinction in International Relations?" (1980) 11 N.Y.I.L. 65; O. Schachter, "The Twilight Existence of Nonbinding International Agreements" (1977) 71 A.J.I.L. 296.

See, for example, G.J.H. van Hoof, Rethinking the Sources of International Law (Deventer, The Netherlands: Kluwer Law and Taxation Publishers, 1983) at 187-191. Bernhardt, supra note 9 at 61 , states that "Soft law may ... be the precursor of new customary law." The extent to which soft law can be "binding" is discussed by van Hoof, supra note 10 at 188-189. According to Bernhardt, supra note 9 at 61 , soft law comprises:

rules which are neither strictly binding nor completely void of any legal significance; it can be found in documents of international conferences like the Helsinki Conference and Final Act on Security and Cooperation in Europe or in resolutions of international organizations....

A similar definition states that "'soft law' consists of documents that are not legally binding upon states (and hence are not directly enforceable in courts and tribunals) but that nonetheless may have an impact upon international relations, and, ultimately, international law." D.J. Harris, Cases and Materials on International Law, 4th ed. (London: Sweet \& Maxwell, 1991) at 65. 
imprecise." 14. This third characterization of soft law highlights the process of transforming general norms of inter-state behaviour into more specific legal rules.

The parallel between Canadian intergovernmental cooperation in EA and the relationship between hard and soft law in the international context is as follows: diplomacy is used to advance from the formulation of general principles to the adoption of legally binding rules and formal intergovernmental arrangements. As Saunders argues: ${ }^{15}$

soft law has been used [in the international context] as a means of encouraging the evolution of law in precisely those broad areas of environmental management that require global solutions but which involve a movement away from strict insistence on sovereignty towards a greater emphasis on shared responsibility. ... While the domestic adoption of soft law does not in itself portend a new division of environmental powers between national and sub-national governments, one can at least in a Canadian context point to the growing use of framework agreements and accords in federal-provincial cooperation on natural resources and environmental management that bear some similarity to ... framework conventions ... in the context of international law.

The soft law - hard law analogy thus refers not simply to two somewhat arbitrary categories of rules or principles, but also to the process which leads towards greater legal status and formality of intergovernmental relations. This focus on process makes the international paradigm particularly germane to Canadian intergovernmental cooperation in EA. ${ }^{16 .}$

\section{THE CONSTITUTIONAL CONTEXT}

Constitutional law provides the context within which intergovernmental relations develop. ${ }^{17}$. Applying the international analogy, the Constitution defines the nature and extent of sovereignty within the federal system. The significance of the Constitution is tempered by the fact that it imposes remarkably few constraints on the development of non-constitutional techniques to complement, or even circumvent, the formal allocation

R. Dupuy, "Declaratory Law and Programmatory Law: From Revolutionary Custom to 'Soft Law" in R. Akkerman \& P.J. van Krieken, eds., Liber Röling, Declarations on Principles; A Quest for Universal Peace (Leyden: Sijthoff, 1977) 252, cited in van Hoof, supra note 10 at 187. The imprecision of soft law allows a degree of flexibility which constitutes one is its principal advantages in international relations. See van Hoof, supra note 10 at 189; Bothe, supra note 9 at 88, 90-92; P. van Dijk, "The Final Act of Helsinki - Basis for a Pan-European System?" (1980) 11 N.Y.I.L. 97 at $115-118$. Saunders, supra note 3 at 23.

In addition, an institutional reason for the applicability of the paradigm is suggested by van Hoof's statement, supra note 10 at 189 , that "...because of the lack of a formal organizational structure, "softlaw' rules play a more prominent role [in international law] than in national legal systems and are likely to do so also in the future." The weakness of organizational structures and procedures for establishing legal rules of intergovernmental relations is evident in both the international system and Canadian federalism. 
of powers. ${ }^{18 .}$ Nonetheless, the central problems of intergovernmental relations are a function of the constitutional framework which, in the case of environmental management in general and EA in particular, creates significant potential for jurisdictional overlap and conflict. ${ }^{19 .}$

The constitutional position of EA was most recently discussed by the Supreme Court of Canada in its 1992 decision in Friends of the Oldman River Society v. Canada (Minister of Transport). ${ }^{20}$. Litigation was initiated in response to a decision by the Government of Alberta to build an irrigation dam on provincial lands in the southern part of the province. The project had consequences for matters of federal jurisdiction, including fisheries, Indians and lands reserved for Indians, and navigable waters. A federal permit was also required under the Navigable Waters Protection Act. ${ }^{21}$. Consequently, it was argued, the project should be submitted to a federal EA. In considering the applicability of the federal EA regime, the Court discussed the extent of federal constitutional jurisdiction against the backdrop of broad provincial responsibilities regarding the environment.

The Court's constitutional reasoning can be summarized in five points. ${ }^{22}$ First, the Court affirmed that the environment is not a distinct area of jurisdiction under the Constitution. Rather, environmental jurisdiction is derived from a number of heads of power of both levels of government. ${ }^{23}$.

Second, the Court held that environmental assessment is "an integral component of sound decision-making.... In short, environmental impact assessment is simply descriptive of a process of decision-making. "24. This finding affirms that, from the constitutional perspective, EA has an "auxiliary nature"25. and may be applied whenever governments

See Hogg, supra note 6 at 130-133 for a discussion of how "cooperative federalism" permits constitutional adaptation. Federal inter-delegation, discussed at 353-367, provides a striking example of constitutional flexibility achieved through intergovernmental arrangements.

As Saunders notes, the problem of "concurrent sovereignty within the same physical boundaries" is exacerbated in federal systems "where the constitution defining the sovereign rights of each level of government is silent or ambiguous as to the respective responsibilities over some particular subject." Saunders, supra note 3 at 14 . The subject of environmental management is not explicitly mentioned in the Constitution. For analyses of environmental jurisdiction in Canada, see: D. Gibson, "Constitutional Jurisdiction Over Environmental Management in Canada" (1973) 23 U.T.L.J. 54; G.A. Beaudoin, "La protection de l'environnement et ses implications en droit constitutionnel" (1977) 23 McGill L.J. 207; D. Tingley, ed., Environmental Protection and the Canadian Constitution (Proceedings of the Canadian Symposium on Jurisdiction and Responsibility for the Environment) (Edmonton: Environmental Law Centre, 1987); J.B. Hanebury, "Environmental Impact Assessment in the Canadian Federal System" (1991) 36 McGill L.J. 962; A.R. Lucas, "Constitutional Powers" in R. Cotton \& A.R. Lucas, Canadian Environmental Law, 2d ed., vol. 1 (Toronto: Butterworths, 1992).

[1992] I S.C.R. 3 [hereinafter Oldman].

R.S.C. 1985 , c. N-22, s. 5.

A more detailed discussion of Oldman, on which the following summary is based, is found in S.A. Kennett, "Federal Environmental Jurisdiction after Oldman" (1993) 38 McGill L.J. 180.

Oldman, supra note 20 at $63-64$.

Ibid. at 71.

Ibid. at 72. 
exercise decision-making jurisdiction. ${ }^{26}$ Both levels of government thus have EA authority.

Third, the judgment supports an argument that federal environmental jurisdiction extends to two categories of activities. The first category includes activities explicitly designated in the Constitution as matters of federal jurisdiction, such as interprovincial railways. ${ }^{27}$. These activities are subject to comprehensive environmental jurisdiction since all of their environmental effects may be regulated by Parliament. ${ }^{28}$. The second category of activities are those with effects on areas of federal jurisdiction. ${ }^{29}$. For example, while the construction of a project like the Oldman River Dam is not identified in the Constitution as an activity within federal jurisdiction, Parliament may regulate the project with respect to its effects on matters of federal authority, such as fisheries and navigable waters. Jurisdiction that is confined to the regulation of effects on particular areas of authority can be referred to as restricted jurisdiction.

The fourth point, following directly from the third, is the Court's rejection of the argument that a project such as the Oldman River Dam is a "provincial project" which, because of extensive provincial jurisdiction, is immune from federal regulation. ${ }^{30}$. Although federal jurisdiction may be restricted to the project's effects, the exercise of this authority has undeniable constitutional legitimacy.

The fifth point in Oldman is the recognition of constitutional limits on the exercise of regulatory authority through EA. La Forest J. introduced the issue of constitutional limits as follows: ${ }^{31}$.

I am not unmindful of what was said by counsel for the Attorney General for Saskatchewan who sought to characterize the Guidelines Order as a constitutional Trojan horse enabling the federal government, on the pretext of some narrow ground of federal jurisdiction, to conduct a far ranging inquiry into matters that are exclusively within provincial jurisdiction.

The court held that the extent of EA jurisdiction is related to the nature of the powers on which it is based. ${ }^{32}$. La Forest $\mathrm{J}$. found that the mandate for federal EA under the Guidelines Order $^{33}$ is only ${ }^{34 .}$

The Court underlines this conclusion by finding that EA, as a "procedural or organizational element" of the federal government's internal decision-making process, is supported by the residual "peace, order and good government" power (ibid. at 73-74).

This example is discussed by La Forest J., ibid. at 65-66.

Ibid. at 66.

This category is based on the examples discussed by La Forest J., ibid. at 66-68, 72.

Ibid. at 68-69.

lbid. at 71-72.

Ibid. at 67,72 .

Environmental Assessment and Review Process Guidelines Order, SOR/84-467, s. 6. The Guidelines Order was established pursuant to the Department of the Environment Act, R.S.C. 1985, c. E-10, s. 6.

Oldman, supra note 20 at 72 . 
to examine matters directly related to the areas of federal responsibility affected. Thus, an initiating department or panel cannot use the Guidelines Order as a colourable device to invade areas of provincial jurisdiction which are unconnected to the relevant heads of federal power. [emphasis added]

In cases of restricted jurisdiction, the use of EA to extend regulatory authority to all aspects of a project would be colourable and unconstitutional. ${ }^{35}$.

In Oldman, the Supreme Court of Canada defined the basis of federal EA jurisdiction and identified constitutional limits to prevent undue intrusion on the provinces' environmental authority. The constitutional position does not, however, resolve the difficulties for the federal system created by EA.

\section{LIMITATIONS OF THE CONSTITUTIONAL POSITION}

The constitutional position defined in Oldman has three limitations relevant to the practical problems of duplication, delay and uncertainty caused by overlapping EA jurisdiction. The first of these limitations is the weakness of the constitutional constraint on federal jurisdiction. The complex interrelationships of cause and effect within ecosystems and the difficulty of establishing a direct link between the factors evaluated in an EA and subsequent regulatory decisions may make the colourability constraint awkward to enforce. Once a jurisdictional toe-hold for EA is established, the courts may be unwilling or unable to identify clearly the point where the scope of an EA renders it colourable. Consequently, the potential for overlap in EA processes may be greater in practice than is suggested by the constitutional theory enunciated in Oldman.

The second limitation of the constitutional position in Oldman is the incompatibility between restricted jurisdiction and the philosophy of holistic or comprehensive EA. The effectiveness of EA depends on its comprehensiveness for two reasons. First, a comprehensive approach is needed to evaluate interrelationships between environmental effects. The chain of consequences emanating from a project frequently will not respect jurisdictional boundaries, and can best be understood and evaluated from an ecosystem perspective. The second reason for comprehensiveness in EA is to permit a global assessment of costs and benefits. Consider, for example, a dam where the consequences for federal jurisdiction are limited to effects on fisheries. If the federal EA is restricted to an examination of these effects, how could a judgment be made whether minimal harm to fisheries is justified in light of the benefits of the project in another area? The constitutional restriction on EA established by Oldman is thus at odds with the objective of a comprehensive evaluation of projects and their effects. ${ }^{36}$.

For a case where the doctrine of colourability was used to strike down legislation, see Reference $R e$ the Upper Churchill Water Rights Reversion Act, [1984] 1 S.C.R. 297. This case is analysed in E. Edinger, "Case Comment" (1985) 63 Can. Bar Rev. 203.

The difficulties of reconciling federalism with the policy requirements of ecosystem management extend beyond the context of EA. See M. Walters, "Ecological Unity and Political Fragmentation: The Implications of the Brundtland Report for the Canadian Constitutional Order" (1991) 29 Alta L. Rev. 420. 
The third limitation of the constitutional position is that it fails to resolve the fundamental administrative problem of duplication in situations where projects trigger two or more EA regimes. The constitutional analysis in Oldman defines the basis for EA jurisdiction in Canada, but it cannot ensure that governments exercise their respective "sovereign" authority in an efficient and coordinated manner. ${ }^{37 .}$ In light of these limitations of the constitutional position, governments in Canada have turned to diplomacy and the development of soft law to coordinate EA regimes.

\section{THE DEVELOPMENT OF INTERGOVERNMENTAL DIPLOMACY AND SOFT LAW}

The initial response to the intergovernmental dimension of EA was the negotiation of ad hoc agreements. ${ }^{38}$. These arrangements included an umbrella agreement between Canada and Alberta ${ }^{39}$ and a series of project-specific agreements. ${ }^{40}$. The emergence of EA as a significant irritant in intergovernmental relations, however, led to the creation of a multilateral process under the aegis of the Canadian Council of Ministers of the Environment (CCME). This process of intergovernmental diplomacy produced agreement on general principles governing EA cooperation and the adoption of a model framework agreement for bilateral cooperation in EA. The process is briefly described in this section.

CCME is the principal forum for Canadian intergovernmental cooperation on environmental matters. ${ }^{41}$. The Council of Ministers, comprised of environment ministers from the provinces, territories and the federal government, meets at least twice a year. ${ }^{42}$. CCME also serves an important function at the bureaucratic level, coordinating intergovernmental committees and task groups of officials. A permanent secretariat provides administrative, policy and communications support to the Council of Ministers, the Deputy Ministers Committee and the other committees and task groups.

This issue is discussed in S.A. Kennett, "Oldman and Environmental Impact Assessment: An Invitation for Cooperative Federalism" (1992) 3 Constitutional Forum 93-96.

For a discussion of EAs conducted under some of these agreements, see: M. Ross, "An Evaluation of Joint Environmental Impact Assessments" in M. Ross \& J.O. Saunders, eds., Growing Demands on a Shrinking Heritage: Managing Resource-Use Conflicts (Calgary: Canadian Institute of Resources Law, 1992) at 322; P. Edwards, The Al-Pac Review Hearings: A Case Study (Edmonton: Environmental Law Centre, 1990).

39 Agreement Concerning Environmental Impact Assessments of Projects in Alberta with Implications for Canada and Alberta (15 May 1986). This agreement, which lapsed at the end of its three year term, was a subsidiary agreement under the Canada-Alberia Accord for the Protection and Enhancement of Environmental Quality (8 October 1975).

to See, for example: Terms of the cooperative review of the Alberta-Pacific Forest Industries Inc. pulp mill, contained in Alberta, Department of the Environment, Ministerial Order No. 08/89 (Edmonton: 11 July 1989); Canada-Nova Scotia Agreement for the Establishment of a Federal-Provincial Environmental Assessment Review Panel to Conduct a Public Environmental Assessment Review of the Proposed Halifax-Dartmouth Metropolitan Sewage Treatment Facility (21 November 1990); Canada-Manitoba Agreement on Terms of Reference for a Federal-Provincial Panel to Conduct a Public Environmental Assessment Review of the Proposed Conawapa Project (24 May 1991).

41 Information on the CCME is contained in Canadian Council of Ministers of the Environment, Annual Reports (1989-1990, 1991-1992).

42 Quebec did not participate in the Council of Ministers and CCME committees and task groups from June 1990 until the spring of January 1993. 
CCME's interest in EA can be traced to the Statement of Interjurisdictional Cooperation on Environmental Matters, issued in 1990. ${ }^{43}$. This document included a principle of timely notification and appropriate consultation "where one jurisdiction's legislation, regulations, policies, programs, and projects affect another jurisdiction." 44. Ministers also agreed to work towards "the harmonization of environmental assessment and review procedures" and "the development of bilateral accords and issue-specific agreements to promote environmental cooperation between and among governments. ${ }^{145}$.

The next stage in the CCME process was agreement on Cooperative Principles for Environmental Assessment, approved by the Council of Ministers in 1991. ${ }^{46 .}$ This document affirms that: "It is critical that the environmental assessment process be cost effective, provide for a minimum of uncertainty and duplication and encourage

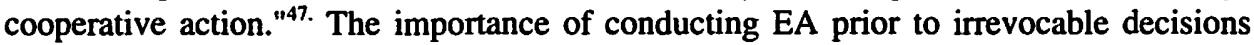
being taken is also noted. ${ }^{48}$. To promote consistent and effective EA across the country, a list of common elements for EA processes was agreed upon. These elements concerned public participation, the scope of the review, the proponent pays principle, the role of EA in project approval and rejection, issue identification, and the use of innovative procedures to improve flexibility and effectiveness. ${ }^{49}$. The document underlines the importance of cooperative mechanisms in specific areas and recommends the consistent application of EA processes across jurisdictions in order to avoid forum shopping. ${ }^{50}$. Finally, it states that "Decisions arising from environmental assessments will be made by each jurisdiction within the limits of its legislative competence" and "cannot be delegated to another jurisdiction." ${ }^{51}$. As in the international realm, the extent of cooperation is constrained by sovereignty.

The final stage of the CCME process was the Draft Framework for Environmental Assessment Harmonization. ${ }^{52}$. The limits of multilateral negotiations in the context of diverse EA regimes and political sensitivities require a shift to bilateral diplomacy to work out the details of cooperation. The CCME framework is intended as a basis for bilateral (federal-provincial/territorial) agreements. It begins with general statements regarding the context and rationale for the parties' agreement "to cooperation and coordination in environmental assessment in order to promote effective and consistent environmental assessment processes in Canada and to avoid uncertainty and duplication. ${ }^{\text {"53. The core }}$

CCME, Statement of Interjurisdictional Cooperation on Environmental Matters (March 1990). lbid. at 2.

Ibid. at 3.

CCME, Cooperative Principles for Environmental Assessment (May 1991). These principles were also included in the Atlantic and Western Accords on Environmental Cooperation, signed by provincial and territorial governments in 1991. Both Accords listed "Harmonization of environmental assessment procedures and the development of bilateral environmental assessment agreements" as priorities for action.

lbid. at 1.

lbid.

lbid. at 1-2.

lbid. at 2-3.

Ibid. at 2 .

CCME, Draft Framework for Environmental Assessment Harmonization (November 1992).

Ibid. at 1-2. 
of the framework document is a list of 18 principles and topics to be included in bilateral agreements. Items on this list concern project notification procedures, early identification of the parties' interests and involvement in EA, information sharing, intergovernmental communication and coordination, agreement on time frames for EA, project-specific agreements for joint review panels, assistance to participants, monitoring of and compliance with approval conditions, and inclusion of aboriginal peoples. In addition, the list states that governments other than the parties should participate in EA in cases of transboundary effects, and provides that parties will adhere to the United Nations Convention on Environmental Impact Assessment in a Transboundary Context. ${ }^{54 .}$ This incorporation by reference illustrates the adoption of international law principles to guide Canadian domestic intergovernmental relations.

The CCME framework document lays the groundwork for a bilateral process which will produce umbrella agreements specifying the modalities for coordinating particular EA regimes and, where necessary, project-specific agreements establishing the procedures for joint reviews. As of October 1993, the process is under way in several jurisdictions but has only yielded one bilateral agreement, the Canada-Alberta Agreement for Environmental Assessment Cooperation. ${ }^{55}$.

In summary, this section outlines a process of intergovernmental diplomacy, moving from problem identification and the establishment of a multilateral approach, through the formulation of general principles, to the negotiation of more specific bilateral agreements. The process can also be viewed in legal terms. This perspective focuses on the development and implementation of legal principles, characterized above as soft law.

\section{INTERGOVERNMENTAL AGREEMENTS ON EA AND THE EVOLUTION FROM SOFT TO HARD(ER) LAW}

This legal analysis of intergovernmental cooperation in EA contains two parts. The first is a general discussion of the legal status of intergovernmental agreements. The second part applies this discussion to the developing soft law of EA.

The hardening of legal rules governing intergovernmental relations is a process whereby obligations and legal arrangements increase in formality, specificity and legal status. The term "legal status" is preferable to "enforceability" because the latter word can be used in two ways in the context of intergovernmental agreements. ${ }^{56}$. In one sense, intergovernmental agreements are generally unenforceable. The constitutional principle that legislatures cannot bind their successors means that, unless intergovernmental

ss Canada-Alberta Agreement for Environmental Assessment Cooperation (6 August 1993). This agreement is accompanied by two subsidiary agreements which provide guidelines for the establishment of "Joint Panel Reviews" and "Designated Offices/Notification Procedures." 
agreements are formally incorporated into the Constitution, ${ }^{57}$ they cannot be enforced against a government determined not to be bound. ${ }^{58}$. Governments are thus in a fundamentally different position from private parties to contracts in that they can avoid obligations by enacting legislation inconsistent with prior agreements. ${ }^{59}$ A provision in the 1992 constitutional reform package agreed to in Charlottetown was intended to alter this situation by preventing unilateral change to specially designated intergovernmental agreements. ${ }^{60 .}$

There is, however, a second way of viewing the enforceability of intergovernmental agreements. Where governments do not wish to avoid their commitments under agreements, the legal status of these agreements may be recognized by the courts and parties, or even third parties in the case of agreements embodied in legislation, ${ }^{61 .}$ may obtain judicial interpretation and enforcement. One means of placing intergovernmental agreements before the courts is provided for by s. 19 of the Federal Court Act ${ }^{62 .}$ which states that, where provincial governments agree, ${ }^{63 .}$ the Federal Court has jurisdiction over federal-provincial and interprovincial controversies. Governments may thus litigate to clarify their obligations and to resolve disputes arising under agreements. In addition, as will be shown below, courts may attach legal significance to intergovernmental agreements in contexts other than adjudication by the Federal Court. When tracing the development and hardening of soft law in this section of the article, it is this second sense of enforceability which is of interest and which is encompassed by the term "legal status."

The legal status of intergovernmental agreements is clearest when these agreements are embodied in legislation and therefore have the full force of law. ${ }^{64}$. For agreements not

The constitutionalization of intergovernmental agreements is illustrated by the entrenchment of the Natural Resources Transfer Agreements, granting resource ownership rights to the western provinces, in the Constitution Act, 1930, 20-21 Geo. 5 c. 26 (U.K.). Reference Re Canada Assistance Plan (B.C.), [1991] 2 S.C.R. 525. See also S. Blackman, Intergovernmental Agreements in the Canadian Administrative Process (in press).

Governments may also be able to avoid their obligations through executive action. The issue of whether non-legislated intergovernmental agreements can constrain the executive is discussed in Kennett, supra note 56 at 74-76. The leading case on this issue is Rederiaktiebolaget Amphitrite $v$. R., [1921] 2 K.B. 500.

Canada, Privy Council Office, Charlottetown, Consensus Report On the Constitution (28 August 1992) s. 26 ("Protection of Intergovernmental Agreements"). Finlay v. Canada (Minister of Finance), [1986] 2 S.C.R. 607; Finlay v. Minister of Finance of Canada (1993), 150 N.R. 81 (S.C.C.). R.S.C. 1985 , c. F-7.

63 All provincial governments except Quebec have agreed to Federal Court jurisdiction. British Columbia, however, has passed legislation, not yet in force, which would withdraw its agreement. See Statutes Repeal Act, 1990, c. 26, s. 1(5) repealing Federal Courts Jurisdiction Act, R.S.B.C. 1979, c. 126.

The James Bay and Northern Quebec Agreement, to which the governments of Canada and Quebec, the Grand Council of the Crees and the Northern Quebec Inuit Association are parties, is a leading and frequently litigated example of a legislated intergovernmental agreement. The relevant statutes are An Act Approving the Agreement Concerning James Bay and Northern Quebec, S.Q. 1976, c. 46 and James Bay and Northem Quebec Native Claims Settlement Act, S.C. 1976-77, c. 32. The implications of the legal status of this agreement are discussed in Cree Regional Authority v. Quebec (1991), 47 F.T.R. 251. 
enacted as legislation, legal status depends on their characterization by the courts. In this situation, a spectrum exists between "political" agreements and those having a "legal" content. ${ }^{65 .}$ Saunders states that: ${ }^{66 .}$

\begin{abstract}
When an agreement is drafted in the language of typical private law contracts, employing terms such as "binding", "entitled to enforce", "contracts with" or "successors and assignees", it can normally be concluded that some legal force must have been intended for the agreement. This is in contrast to ambiguous, perhaps aspirational, phrases which are more suggestive of political than legal undertakings. Finally, the specification of a mechanism for dispute resolution may be indicative of the legal nature of the agreement. Obviously, an agreement that anticipates resolution of differences by political means (for example, by the agreement of the responsible Ministers) is, other things being equal, far less likely to be read as legally binding than one that provides for arbitration or settlement by a designated court.
\end{abstract}

The substance of an agreement and the specificity of language used are relevant to its characterization. In addition, evidence that a party has relied on or benefitted from an agreement may lead the courts to accord it some legal status.

This general analysis of the legal status of intergovernmental agreements is supported by the decision in Canada (Attorney General) v. Saskatchewan Water Corp. ${ }^{67}$. At issue was an agreement between the Government of Canada and a Saskatchewan Crown corporation incorporated to own and operate the Rafferty-Alameda dam project. The corporation was designated by its constituting statute as "an agent of the Crown." 68. The agreement stated that, in exchange for compensation of one million dollars per month, the corporation would cease dam construction and land acquisition until the federal Minister had the opportunity to implement the recommendations of the federal Environmental Assessment and Review Process (EARP) panel. Following a series of delays, including the resignation of the first EARP panel, the Premier of Saskatchewan announced that the project would proceed and the corporation continued land acquisition and dam construction. The federal Attorney General then sought an interlocutory injunction to enforce the agreement.

The case is significant for the legal status of intergovernmental agreements for three reasons. First, the corporation's status as an agent of the provincial Crown, and the fact that its action breaching the agreement was apparently taken on instructions from the Premier, indicate the intergovernmental nature of this dispute and the underlying agreement. The court's approach to the legal status of the agreement could thus be applied to cases involving agreements directly between governments. ${ }^{69}$.

Kennett, supra note 56 at $63-68$.

J.O. Saunders, Interjurisdictional Issues in Canadian Water Management (Calgary: Canadian Institute of Resources Law, 1988) at 96.

[1992] 4 W.W.R. 712 (Sask. C.A.).

lbid. at 718.

Injunctive relief, however, would be unavailable in an action brought against the Crown. See Hogg, supra note 6 at 264. 
Second, the case illustrates judicial willingness to consider the legal status, and even the enforceability, of an agreement which was not embodied in legislation. While the characterization issue was not addressed in the decision, it is noteworthy that the agreement, which was reproduced in full, has many indicia of legal status. For example, it contains clear obligations $\mathrm{s}^{70}$ and employs traditional contractual language.71. Enforceability in terms of contract law doctrine is suggested by the granting of consideration for the corporation's undertaking not to proceed with construction. ${ }^{72 .}$

The third reason why this case is instructive as to the legal status of intergovernmental agreements is the court's treatment of the enforceability issue. The corporation argued that the agreement concerned a "program" within the meaning of s. 7 of the Department of the Environment $\mathrm{Act}^{73 .}$ and was therefore unenforceable because it had not received approval of the Governor in Council as required by that Act. The court rejected this argument on the grounds that the Rafferty-Alameda project was not a "program." More significant, however, was its reaction to the corporation's argument: ${ }^{74 .}$

The efficacy of this defence should be seriously questioned. It must be remembered that the corporation has benefitted from the January 26 agreement to the tune of $\$ 8,000,000$. Should it now be heard to impugn the transaction so that it can avoid carrying out its end of the bargain? Does that plea lie in the corporation's mouth? A court will look hard and strong to avoid any injustice that would flow from a successful attempt to establish an ultra vires transaction (for a parallel from corporate law, see Breckenridge Speedway Led. v. R. (1967), 61 W.W.R. 257, 64 D.L.R. (2d) 488 (Alta. C.A.)).

Where a party has derived clear benefits from an agreement, the courts may be reluctant to find that the agreement lacks legal status.

The soft law relating to intergovernmental cooperation in EA can now be examined in light of this discussion of the legal status of intergovernmental agreements. Four stages of soft law are identified: the CCME general principles and framework for harmonization, bilateral umbrella agreements, project-specific agreements, and cooperative arrangements or principles embodied in legislation.

The first stage of soft law consists of the general principles of cooperation and the model framework agreement developed through CCME. This stage is best characterized, in terms of the international paradigm, as a "pre-law" version of soft law. The three CCME documents represent a progressive identification and specification of norms for intergovernmental cooperation in EA, but they serve mainly as guidelines and will depend,

70

All six of the substantive provisions of the agreement state that one or other of the parties "agrees" to perform, or refrain from performing, specific actions. Canada (Attorney General) v. Saskatchewan Water Corp., supra note 67 at 723.

71

For example: "In consideration of the Corporation ceasing construction in accordance with this Agreement the minister agrees ... that assistance to offset direct and indirect impacts of the cessation of construction will be provided by the payment of one million dollars per month commencing February 1, 1990,"(ibid. at 723). S.M. Waddams, The Law of Contracts, 2d ed. (Toronto: Canada Law Book, 1984) at 88-91.

R.S.C. 1985 , c. E-10.

Canada (Attorney General) v. Saskatchewan Water Corp., supra note 67 at 734-735. 
for their legal status, upon incorporation into more detailed agreements. Their adoption by the Council of Ministers indicates a general acceptance of these principles within Canada's federal system, but it is not likely to be viewed as formal ratification by the respective governments.

In terms of the characterization spectrum, these documents are "political" agreements in that they tend to be aspirational in tone and lacking in specific obligations, contractual language, dispute resolution mechanisms and other indicia of legal status. They might also be characterized as agreements to negotiate, or as agreements regarding the general structure of subsequent agreements. As such, they would likely be unenforceable under standard contract law principles. ${ }^{75}$. Nonetheless, these documents are clearly intended to provide a structure for intergovernmental cooperation. They fit within the soft law - hard law paradigm since they may guide the behaviour of governments and provide a framework for subsequent obligations having firmer legal status. Furthermore, they might be used to interpret subsequent agreements.

The legal status of bilateral umbrella agreements, the second stage in the development of soft law, will depend on the position of these agreements on the political-legal spectrum. At one extreme, they may be drafted as general framework agreements which establish broad guidelines for cooperation and lay the groundwork for detailed, projectspecific agreements. The 1986 Agreement Concerning Environmental Impact Assessments of Projects in Alberta with Implications for Canada and Alberta ${ }^{76}$ is an example of this type of agreement. It contains eight provisions which establish broad principles and procedures for cooperation. The details of joint EA are not addressed and there are few specific obligations. The dispute resolution mechanism, in the case of a disagreement over which jurisdiction has "primary responsibility" for a project, is "normal intergovernmental consultative procedures" followed, if necessary, by reference to the respective Ministers. ${ }^{77}$. In terms of the indicia of legal status identified by Saunders, ${ }^{78 .}$ this agreement would likely be characterized as "political." It should be noted, however, that this Canada-Alberta agreement was concluded well before the CCME process on intergovernmental cooperation and did not address many of the issues identified in the Draft Framework for Environmental Assessment Harmonization. Consequently, it may not be a model for future bilateral agreements.

At the other end of the spectrum, bilateral umbrella agreements could create comprehensive processes for coordinating EA in cases of jurisdictional overlap. These agreements could consist of detailed provisions which reflect and expand on the CCME Draft Framework for Environmental Assessment Harmonization and which include specific and binding obligations, detailed procedures for matters such as scoping and the appointment of joint panels, and formal dispute resolution mechanisms including, perhaps, reference to the Federal Court. Such agreements could render project-specific arrangements unnecessary in all but exceptional cases and would, following the schema 
outlined earlier, be accorded legal status. They would thus constitute a significant hardening of the "pre-law" CCME principles.

The third stage of soft law will be project-specific agreements. The effectiveness of these agreements will depend on their detailed provisions governing the issues listed in the CCME harmonization framework. For example, matters such as the scope of the EA, information sharing, the single point of contact within each government, the appointment of a joint panel, procedures for administrative delegation, intervenor funding, and other cost sharing will have to be addressed. Obligations in these areas may be phrased in contractual language and the agreements could include formal dispute resolution mechanisms such as arbitration or reference to the courts. Project-specific agreements are also likely to be relied upon by the parties in project planning and the courts may therefore be inclined to accord them legal status. In terms of the characterization spectrum outlined above, these agreements resemble more closely contracts than statements of political objectives or undertakings to negotiate.

Legislation is the fourth stage in the creation of legal obligations regarding intergovernmental arrangements for EA. It represents the final stage, short of constitutional amendment, in the hardening of the soft law of intergovernmental relations. This legislation could be of two types. The first type involves the enactment of intergovernmental agreements. Once embodied in legislation, these agreements achieve a clear legal status and can be referred to the courts for interpretation and application. Legislated agreements are not only binding between the parties; third parties may be able to assert rights and enforce obligations conferred through them. ${ }^{79}$. The enactment of EA agreements would thus ensure that the reliance interest of a third party, for example a project proponent or intervenor, could be legally protected.

The second type of legislative hardening of soft law is the statutory adoption of principles for intergovernmental cooperation in EA. The "pre-law" principles could thus achieve legal status, without going through the process of incorporation into bilateral agreements and judicial characterization. These principles could operate as conditions for cooperative arrangements, thereby shaping agreements and encouraging harmonization. This use of legislation is illustrated by the procedures for intergovernmental cooperation and coordination with similar provincial EA processes contained in the Canadian Environmental Assessment Act. ${ }^{80}$. These provisions codify principles for intergovernmental cooperation in EA in areas such as the appointment, qualifications, impartiality and terms of reference of a joint panel, the factors to be considered by the panel, the taking of evidence and summoning of witnesses, the opportunity for public participation, and the publication of the panel's report. ${ }^{81 .}$ They are also likely to promote the harmonization of EA norms in Canada. Provincial governments, anxious to preserve

79

81

Finlay v. Canada (Minister of Finance), supra note 61. See also N. Bankes, "Co-operative Federalism: Third Parties and Intergovernmental Agreements and Arrangements in Canada and Australia" (1991) 29 Alta L. Rev. 792. Bill C-13, Canadian Environmental Assessment Act, 3d Sess., 34th Parl., 1992 at ss. 12(4), 17(1), 40$42,46-48$.

Ibid. at s. 41 . 
their jurisdiction or sovereignty in environmental and natural resource management, are likely to adapt their EA regimes to the federal provisions as a way of limiting the application of federal EA to projects within their boundaries. While the federal legislative provisions are not legally binding on the provinces, the incentives for provincial compliance in order to achieve equivalent status are considerable.

The four stages of the hardening of soft law described in this section show how the legal framework for intergovernmental cooperation in EA may progress from an initial agreement on general principles to the enactment of specific and binding procedures and obligations. The final section of this paper considers briefly the prospects for this development.

\section{PROSPECTS FOR THE HARDENING OF THE LAW GOVERNING INTERGOVERNMENTAL COOPERATION IN EA}

The process outlined above has yet to reach its conclusion. The CCME framework for bilateral agreements was released in November, 1992 and the Canada-Alberta bilateral agreement was signed in August 1993. Two or three stages thus remain to be completed in most provinces. These stages are the negotiation of bilateral umbrella agreements and, if necessary, project-specific agreements. These agreements might then be accorded legislative status. The full development of a legal regime for intergovernmental cooperation in EA remains a significant challenge for Canadian federalism for four reasons.

The first is the number and diversity of systems to be coordinated. Canada has different EA regimes in each province and at the federal level, and municipal planning processes may also involve EA. These systems vary significantly in their level of complexity and sophistication, and in the details of their application. In addition, the enactment in 1992 of new federal EA legislation ${ }^{82}$ and ongoing processes of amendment and wholesale review $^{83 .}$ of provincial laws mean that EA in Canada is in a state of flux.

Second, as is typical in Canadian intergovernmental relations, governments are frequently anxious to protect their sovereignty and are wary of any perceived erosion of authority or intrusion into traditional areas of responsibility. ${ }^{84}$ Jurisdictional defensiveness is intensified because the projects to which EA applies may have significant political and economic stakes. Quebec's James Bay hydro development and the Oldman River Dam in Alberta are examples of projects actively sponsored by provincial

Ibid.

See Saskatchewan Environmental Assessment Review Commission, Environmental Challenges (Regina: Saskatchewan Environment and Public Safety, 1991); Ministry of Environment, Lands and Parks and Ministry of Energy, Mines and Petroleum Resources, Reforming Environmental Assessment in British Columbia: A Legislation Discussion Paper (March 1992).

Quebec's Minister of the Environment characterized the Canadian Environmental Assessment Act as "totalitarian" and "domineering" and promised "judicial guerrilla warfare at every level." "Judicial warfare' promised," The /Torontol Globe and Mail (24 June 1992) A4. Quebec has refused to proceed with negotiating a general federal-provincial arrangement regarding EA until its concerns with the Canadian Environmental Assessment Act are addressed. 
governments which have generated EA disputes. Provincial sensitivity to perceived federal interference ${ }^{85}$. with natural resource management is particularly acute in the context of major projects such as these which are, of course, especially likely to trigger federal EA responsibilities.

The third reason is the myriad of technical issues to be addressed in detailed agreements. Progressing beyond general principles will require careful consideration of specific issues such as the appointment and operation of joint panels, cost sharing and intervenor funding arrangements, the coordination of time frames for different stages of EA procedures, and the establishment of dispute resolution mechanisms. Agreement on these and other points may be difficult.

A fourth reason for difficulties in intergovernmental cooperation in EA may arise if a choice between EA regimes is deemed necessary to avoid the creation of a separate EA process in cases of overlapping jurisdiction. The establishment of a mechanism to select the applicable system where both levels of government have important interests may be a major challenge. This issue also illustrates the difference between the constitutional position and the soft law produced by intergovernmental relations. The Oldman decision rejected the argument that, because of the predominant provincial interest in and jurisdiction over the dam, it was a "provincial project" to which the federal EA regime did not apply. However, if a choice of EA regimes is necessary to avoid duplication in projects of this type, the notion of "provincial project" may have to be revived through the soft law of intergovernmental agreements. Furthermore, once established in formal or legislated agreements, this designation of projects would obtain legal status.

This application of soft law to modify the constitutional position is illustrated by the decision in Eastmain Band v. Canada (Federal Administrator), ${ }^{86 .}$ where dicta interpreting the James Bay and Northern Quebec Agreement characterize the Eastmain 1 Project as "provincial" for the purposes of EA. The court's finding is consistent with the constitutional position in Oldman that, regardless of the balance between federal and provincial authority and interests with respect to a project, federal EA is constitutional if the project has effects on areas of federal authority. The Eastmain decision, however, affirms the legal status of an agreement designed to avoid duplication in EA by designating the project in question as "provincial" and thereby not subject to the federal EA regime. The Eastmain dicta thus indicate the potential for a legal framework, generated through diplomacy and enacted in legislation, to regulate EA when projects are subject to overlapping jurisdiction. Achieving that potential may not always be easy.

Against these reasons, however, must be weighed the substantial cost of overlapping, inconsistent and duplicative EA procedures, the negative consequences for economic development of undue delay and uncertainty in regulatory decision-making, the demands by environmental groups and the public at large for fair and accessible EA procedures, deference to provincial jurisdiction. In Oldman, it was literally forced into court by environmentalists seeking application of the federal EA regime. 
and the desire of governments to prevent important development projects and environmental management issues from becoming sources of intergovernmental conflict. Litigation surrounding major interjurisdictional projects such as Alberta's Oldman River Dam, Saskatchewan's Rafferty-Alameda project and Hydro-Québec's James Bay development has underlined the need for cooperative EA arrangements. These factors provide the impetus for significant efforts to coordinate and rationalize EA in Canada. The incentives for cooperation and the progress already made in the elaboration of soft law suggest that this process has considerable momentum.

\section{CONCLUSION}

The hard law - soft law paradigm described in this article focuses on the evolution of intergovernmental cooperation in EA. This evolution is achieved through the medium of intergovernmental diplomacy and against the backdrop of constitutional law. The paradigm directs attention to both political and legal features of intergovernmental relations. The central feature, from a political perspective, is the role of soft law as an instrument for addressing the policy issues produced by overlapping EA jurisdiction in the federal system. This feature is analogous to the use of soft law to address problems posed by sovereignty in the international system. From the legal perspective, the paradigm highlights the development of a legal framework, beginning with general principles and culminating in formal and detailed agreements. These agreements can have legal status and may be embodied in legislation. The paradigm thus shows how law and diplomacy can work together in structuring intergovernmental arrangements within Canadian federalism and serves as a model for intergovernmental cooperation in areas other than EA. 